\title{
Leadership as a driver for organizational change
}

\author{
Shvindina Hanna \\ Ph.D. in Economics, Associate Professor, Sumy State University, Ukraine. \\ (C) The Authors, 2017. This article is published with open access at ARMG Publishing.
}

\begin{abstract}
The paper aims to review the dominating literature and recent findings on leadership phenomenon and its role in organizational change. The studies in sphere of strategic management, organizational theories and social development theories were analyzed to reveal the main features of the leadership. A four-element model for leadership change is proposed, mostly based on the mediating role of transformational leader. The change forces are presented as a combination of transformational leader, the change agents, the change operators and the environment (including endogenous and exogenous factors). As an alternative for competition between transformational leaders and transactional leaders, this paper introduces the network leadership, more beneficial in terms of rapid organizational transformation.
\end{abstract}

Keywords: transformational leadership, transactional leadership, organizational change, organizational development, network leadership, change forces.

JEL Classification: I20, I21, M12, M14.

\section{Introduction}

The organizational change is closely coupled with strategic management since the last considers that constant search for new ways and tools of management is unavoidable and thus, that organizational transformation is a consequence of managerial action. In a process of strategic management, the main challenge is not so much the goals achievement as the retention of achieved (Aaker, 1989). In modern turbulent business environments (Liu, 2013), the sustainability of competitive advantage becomes urgent (Reed \& De Fillipi, 1990; Oliver, 1997). One of the answers to this challenge is to construct the organizational architectonics in such a way that would allow modifying the organizational goals without the key resources loss or competences leakage. As authors assume from the market evidences of pioneers dominance (Golder and Tellis, 1993), the best way to adopt the changes is to become a change maker and to "order" the industry transformations.

The organizational development could be very diverse and it includes various directions. Its representatives are crisis-managers, mediators, strategists and consultants in decision-making, engineering professionals and change leadership couches (Porras \& Robertson, 1992). The modern environment puts the organizations into the reality when the strategists should be aware about possibilities to raise the development viability and create the active framework for continuous constructive changes. The research presented in the paper is a systematic literature review on two main research subjects - organizational change theories and leadership literature aimed to provide an integrative and applicable organizational change model.

\section{Literature review}

Among the most widespread models of organizational development we should name Greiner's Model of Evolution and Revolution (1972), and, of course Corporate Life Cycle offered by Adizes (1979). The dominating approaches in the organizational change literature are presented by the organizational ecology approach of Hannan and Freeman (1977), the organizational changes classification of Van de Ven and Poole (1995), by overview done by Armenakis and Bedeian (1999), the institutional approach offered by Powell and DiMaggio (2012) and others, mentioned below in the Results section. The researchers in a sphere of organizational change and development are numerous as the field is crossing several research directions: organizational change itself, theory of organization, theory of firm, strategic management and innovation. Leadership studies are considered to be one of the most important points in the innovation studies, last three decades brought a lot of insights and challenges into the field, for instance, systematic review done by Bass (1999) and his co-authors (Avolio et al., 1999), meta-analysis of gender-specified leadership style (Eagly et al, 2003); study on personality-based leadership behavior (Rubin et al, 2005), research on dependence of firm's innovation on transformational leadership (Jung et al, 2008; Sarros et al, 2008), the role of support of leader for organizational innovation (Eisenbeiss et al., 2008; Gumusluoğlu \& Ilsev, 
2009); analysis of relatedness of transformational leadership and organizational performance (Wang et al., 2011; Garcia-Moralez et al., 2012) - and still continue to enrich complementary fields.

Nevertheless the papers devoted to organizational change increasingly refer to the phenomenon of leadership, the main questions of wich are still unanswered: in what way leadership transforms the organization, catalyzes innovation, and the most important question - how to model and forecast the leadership influence?

The type of the environment may identify the path of organizational change and the leadership can play certain role in mediating between the environment factors.

\section{Method}

The paper aims to review and synthesize the contributions from previous studies on organizational theories and leadership literature to offer a certain integrative view of the leadership role. More than 50 papers were selected according to their relevance and the number of citations given by Google Scholar Rating. All the papers were read, summarized and classified by theme. The main ideas, findings and insights were analyzed and compared to reveal the key features of leadership through the prisms of organizational change, strategy development and behavior analysis approaches.

\section{Results}

Overview organizational change theories. The organizational change is a research field that has many experts and followers. We should emphasize the interdisciplinary nature of the research on organizational changes and development. The comparative analysis of the terms "strategy" and "organizational development" that was recently done (Shvindina, 2016) brought the assumption that any strategy aims to improve at least one of the organizational elements, while organizational development is a case of strategy of the organization, where the role of transformational leaders is admitted as significant.

The term "organizational change" is the primary definition for our research and authors partly agree with the initial two-dimensional view offered by W. Barnell and G. Carroll (Barnell and Carroll, 1995):

1. Content-based analysis which is considering the organization before and after the changes occurred, and in this case the organizational change is "as a transformation of an organization between two points in time" (ibid, p. 219).

2. Process-based approach according to which such characteristics of the process are taken into account: the speed of changes, types of activities, specifics of the communication and decision-making processes that in combination create new organizational formation.

Authors think that there must be at least one more dimension for the analysis - causes-consequences analysis as the fundament to understanding the preconditions of the process and content of organizational changes. As it was mentioned by R. Merton even if there are purposive actions (under suggestion that human being acts 'rationally'), "unforeseen consequences" (Merton, 1936, p. 895) can appear as unintended results. Therefore, at least two outcomes of purposive action can be identified - intended and unanticipated, which in turns appeared to be caused by organized efforts and spontaneously, not formally organized. This thought was cleared up by $\mathrm{H}$. Mintzberg in his work where he formulated the concept of strategies formulation and realization. Intended strategies that were implemented are named as deliberate and "realized strategies there were never intended" are called as emergent strategies (Mintzberg, 1978, p. 945). Thereby, the causes-consequences analysis is another dimension of the organization changes research.

On the one hand, the experts and analysts agree that both sides of the organization must be evaluated as process either the content side, on the other - they have different opinions about the source and drivers of the changes. These opinions can be distinguished into two groups of theories: those which present internal drivers as primary source of organizational development and suggest that there is inherited program of evolution, and another group - theories that explain the changes as a result of spontaneous reactions to the environmental challenges (external sources of changes).

As for the internal sources of changes, we should name several study flows in the sphere of changes explanation through the endogenous factors. Most of the theories consider organizations in terms of age and size characteristics, which can be differed by stages of organizational life cycle (Greiner, 1972; Adizes, 1979). Life-Cycle Theories use the analogy of organic growth during the life time of the organization as the main idea and explanation of the changes. Using the analogy with the organism that has a development code 
in it, the DNA, and it determines the stages of the organism's changes, Life-Cycle theories are based on evolution theory with the same suggestion about inherited code of organizational development that initiates and determines the organizational changes. The idea of built-in evolutional program was provided as Natural Selection Model by H. Aldrih and J. Pfeffer (Aldrich, Pfeffer, 1976) and Organizational Ecology Theory by M. Hannan and J. Freeman (Hannan and Freeman, 1977). In our opinion, this approach has certain limitations: there must be additional research to prove that all typical organizations have typical stages, the same problems of growth and the typical development path.

Another big shift in studies about the internal drivers of changes was performed by the Garbage-Can Theory, the authors of which are Michael Cohen, James March and Johan Olsen. They considered organization as a collection of problem-oriented choices and decision-makers looking for work (Cohen et al., 1972, p. 2). According to this approach, there are four streams considered: a stream of choices, a stream of problems, a rate flow of solutions, and a stream of energy from participants (Cohen et al., 1972, p. 3). The organizational changes, hereby, can be the result of the participants' movement from one choice opportunity to another, as well as problems and solutions move too. The echo of this view we may see in H. Mintzberg's definition of the strategy as a "pattern in a stream of decisions" (Mintzberg, 1978, p. 934), where the Game Theory, the theory of organizational choice and structural theories of changes were united.

More recent studies in the field of organizational development argue that organizations become inert over time (Hannan \& Freeman, 1984). This theory was supported by further empirical studies (Amburgey et al., 1990), where it was proved that the risk of failure is strongly age dependent. Other findings on contrary showed that larger organizations have better access to strategic resources and win technological innovation competition (Sørensen \& Stuart, 2000), that testifies their mobility, not inertness.

The external factors of organizational changes were recently discussed in academic literature. The researchers examined the environment and institutional system as the condition for the organizational development. The institutional approach to organizational changes was performed by J. Meyer (Meyer, 2010) and later by W. Powell, P. DiMaggio (Powell, DiMaggio, 2012), the main idea of which is that organization follows norms and standards, established by society (or organizational groups) to legitimate its activity.

Comparing different studies about organizational action, we may mention paper, presented by T. Halliday, M. Powell and M. Granfors (Halliday et al., 1993), where it showed that inertial organizations do not change until almost forced to do so by resources depletion or another crisis (state bar associations as a case). This thought is presented in a stream of Conflict Theories, where the development is a process of continual battle with the internal crisis (or inertia in our case) as a reaction to the environment challenges. The New Marxism sociologists (J. Brewer, 1987; Burawoy, 2003) and game-theory researchers (Swedberg, 2001) have common idea about the battle for domination between the representatives of different social segments, in a case of game theory - between the players who have to play with each other according to some informal rules or prescribed formal rules.

Other sphere of explanation for the changes is dialectical model which was described by A. Van de Ven and M. Poole in their paper. According to these scientists, change takes place when "opposing values, forces, or events gain sufficient power to confront and engage the status quo" (Van de Ven \& Poole, 1995, p. 517). In these terms, the market turbulence can be the force that brings the conflict between the values, between the expectations of the current status-quo and expected status of the organization. The environmental research on organizational change was done through the prism of "technological change" by M. Tushman and P. Anderson (Tushman \& Anderson, 1990). This paper concentrated on the problems that firms face with in a process of innovations adoption. The logic of research combines the structural inertia theory, mentioned above, and environmental theories of changes. At the parallel dimension of the research - in the field of strategic management, strong persuasion exists that organizations change because the environmental pressures force them to do so. The environmental challenges can be named in different ways, as turbulent (Kraatz \& Zajac, 2001), as hypercompetition era (D'Aveni, 1998), but they become significant barriers and facilitators for changes.

The special attention should be given to the teleological theories as the approach that stands on crossing borders between endogenous and exogenous explanations of the organizational changes. According to A. Van de Ven and M. Poole (Van de Ven \& Poole, 1995), teleological philosophy assumes that the prime direction, core and end state of the development is desired goal. All the actions, decisions and interactions are dedicated to the goal achievement and once the entity attains its goal, the permanent equilibrium emerged, but the entity 
does not stay in it as further goals reconstruction takes place. As we see, the actor that sets the goal for organizational changes can formulate it from the internal sources or can be directed by external forces. Teleological approach is the widespread view among strategists, and we see it as dominating concept due to which the leadership phenomenon is highly estimated as significant factor in a process of innovations implementation.

\section{Change leadership as a phenomenon to study}

As H. Mintzberg performed in his paper "Patterns in Strategy Formation" (Mintzberg, 1978), the leadership is mediating force between changing environment and organizational operating system (or bureaucracy). Following the logic of his study, the strategy is determined as the set of decisions due to the interactions between three systems of reaction: organization $\leftrightarrow$ environment balance, organization $\leftrightarrow$ environment changes and leadership acceleration. The time and speed of strategic changes are constrained by the bureaucracy force.

The leadership literature presented the transformational leadership as targeted at change and innovations (Bass, 1997; Bass \& Riggio, 2006). Bass presented his concept of the transformational leadership as combination of: idealized influence, inspirational motivation, intellectual stimulation and individualized consideration (Bass, 1997). The transformational leadership is opposite to nontransformational or transactional leadership. While transformational leader is focused on constructive changes, nontransformational is concentrated on status-quo and fostering performance (Bass \& Riggio, 2006). Historically, the differentiation between transformational and transactional leaders appeared through the logic of contradistinction of the roles of manager and leader that was performed repeatedly in academic literature (Burke, 1986; Kirkbride, 2006). For example, W. Burke (Burke, 1986) compared and combined the previous studies into apprehensible approach to clarification of the roles of these types of leaders (see table 1). W. Burke offered such contrasted differences to distinguish and clear up the difference between leadership types: 1) providing direction for followers and subordinates, 2) stimulating followers and subordinates, 3) rewarding followers and subordinates, 4) developing followers and subordinates and 5) appealing to follower and subordinate needs.

Table 1. The differences between transformational leaders and transactional managers

\begin{tabular}{|l|l|l|}
\hline The empowering processes & Transformational leadership (Leader) & Transactional leadership (Manager) \\
\hline Providing direction & Providing the vision and purpose & Providing the path direction \\
\hline Stimulating & Stimulating comes from exciting idea & Stimulating comes from action \\
\hline Rewarding & $\begin{array}{l}\text { Informal and spontaneously, positive re- } \\
\text { inforcement by "strokes" }\end{array}$ & Formal incentives system \\
\hline Developing & $\begin{array}{l}\text { Setting high standards and "impossible" } \\
\text { goals }\end{array}$ & $\begin{array}{l}\text { Involvement into important and relevant } \\
\text { decision-making process }\end{array}$ \\
\hline Appealing & $\begin{array}{l}\text { Appeal to dependency need (followers } \\
\text { need to have a direction) }\end{array}$ & $\begin{array}{l}\text { Appeal to individualism via participation } \\
\text { process }\end{array}$ \\
\hline
\end{tabular}

Source: adapted from Burke, 1986.

Although both the leaders and managers are interested in personal growth of the followers, the types of stimulations are different. The intellectual stimulation offered by transformational leaders encourages the followers to think "outside the box" (Jung, Chow, Wu, 2003) and become innovative thinkers that lead to team innovation.

We should add "creating a capacity for change" (Graetz, 2000) to the mentioned list of the characteristics, it means that the leader becomes the catalyst for innovation ideas that were hidden before and transformed into real after leader's actions. And only then the articulation of the vision and purpose begins. We should add that transactional leaders in this case, can play the opposite role, as antagonists to transformational leaders, by launching different influence strategies (Kanungo, 2001).

Academic scholars and change consultants agree that the organizational change and leadership are highly interconnected. Nevertheless, the role of leadership in change is criticized because of shortage of empirical data, and because the experiments in leadership studies are difficult to replicate. It's still a big question for debates - how leaders transform followers, groups, societies and institutions, how they influenced on the behavior of individuals and groups, if they do.

In their recent paper R. By, M. Hughes and J. Ford presented the most diffused myths about leadership (By et al., 2016) and their disclosure. Their generalization and findings contribute a lot of insights into understanding 
the leadership phenomenon. The main outcomes of the research are: there is no individual leader, leaderships is not enough for change and there is no "on size" rule.

First of all, the leadership does not mean individual leader. Of course, the brightest leaders are remarkable. For example, W. Burke used the example of Mahatma Gandhi as transformational leader. We may name Howard Schultz as an example of transformational leader for coffee-making business or Steve Jobs as person who changed several industries. But actually, these examples stray the researcher away from the nature of leadership which is multiple-functional. Moreover, the individual leaders are less successful in large-scale changes than it was perceived before. The leadership works as partnership, as a system where leader's functions are distributed among multiple people (Gronn, 1999), or management teams (Ensley et al, 2006).). The research on leadership must include new horizons for data search to understand the integrated and distributed leadership (By et al., 2016) or in our mind, cooperative leadership or network leadership. As we assume, if leaders are looking for the followers to lead, they may look for other leaders to share the leadership functions. In this case, they may act as partners - out of competition context - to develop constructive and anticipated organizational changes and they may distribute the functions successfully. This aspect of organizational changes is warranted to be studied in future.

Secondly, the increasing number of literature on the leadership contributions into the successful changes led to assumption that transformational leadership is the key component for the change, and the main one. However, transactional and transformational leaders are complementary according to the studies (Bass \& Riggio, 2006), and following the logic of myths disclosure by mentioned experts (By et al., 2016) we should emphasize on the complexity of differentiation of the real impact of transformational leaders from the impact of other factors. In the organizational internal environment, there is always a place for the conflicts or synergies. The cooperation of the leader with the project teams and operations staff become the source of the innovative breakthroughs, as it was demonstrated by case analysis done for several companies, e.g. Whole Foods, General Electric (Hamel, 2006). The changes outcomes can be and they are the result of combination of numerous factors that led to the certain point in organizational development, and we should not eliminate any of them, including exogenous shock.

In the third place, changes have different characteristics:

$>$ Duration - for instance, Long Waves Theory (Kondratieff, 1979) versus short-term cycles (Martin \& Rogers, 2000).

$>$ Resource constrains for the organizational changes - the discussion was started decades ago (Penrouse, 1955; Hannan \& Freeman, 1984) and continued recently in academic literature (Sirén et al, 2016).

$>$ Path trajectories which may be spiral, non-linear (Weick \& Quinn, 1999; Tsoukas \& Chia 2002) versus dominant linear Greiner's Model (Greiner, 1997).

$>$ Numbers of stages are different - from 3 till 9 stages according to systematic overview (Armenakis \& Bedeian, 1999).

The researchers pointed out that the different variations of change need different types of leadership. For example, K. Weick and R. Quinn offered comparison between episodic and continuous changes with the different roles of change agents (Weick \& Quinn, 1999). In their study, researchers presented the metaphors and analytical framework for understanding of different types of changes and change processes. We cannot say that there is some universal "formula" for leadership that can be replicated with the same result under the same conditions. The leadership is situation-oriented, and the more complex situation is, the bigger number of roles is diffused among the change leaders. At the same time, the leadership is changeable part too, and its value is hard to estimate (Kaiser \& Overfield, 2010).

All these specifics of the leadership phenomenon are the source of limitations of the leadership studies to be replicable and thus taken seriously by empirical researchers.

There are a lot of models that offer the framework for leadership construction, analysis or replication, such as Berke-Litwin Transformational-Transactional Leadership Model, which presents the Causal Model as a linkage between external environment, transactional and transformational variables (Berke-Litwin, 1992), or M. Schneider's Stakeholder Leadership Model (Schneider, 2002). Schneider's Model has the following components: the institutional environment (industrial and extra), industry environment and organizational leadership (ibid, p. 212). The researcher presents organizational leadership as a complex system of radix practices, leader role-sets, leader relationships, leader attributes and leader effectiveness (ibid). 
Inspired by works of the mentioned above scientists, such as Weick, Quinn, Mintzberg, Berke and Schneider we suggest that there is a system of active forces (drivers) of organizational changes that should be analyzed for proofs of interactions.In our study, we offer at the view of least four active forces that interact with each other and they can be the basic elements for the organizational change model:

Transformational Leader - as combination of charismatic, personalized influence (providing the vision, encourage high standards, energizing the followers) and instrumental, competence-oriented professionalism (driver for the innovations, reinforcement for the core competences, communicator with stakeholders). Here we may say that network leadership idea can be implemented for the complex changes when the key leadership roles must be diffused.

1. Change Agents - trust-oriented catalysts with high ability to learn and to transfer knowledge among team members who are developing the change plans and encourage others to follow it.

2. Change Operators are the organizational members who implement the changes into the reality of organization through the standard business-processes and procedures and the new ones, visualized by transformational leader(s) and implemented by change agents.

3. Environment is the sphere of the organizational transformations, it can be an internal system, and business-environment (or extra institutional as Schneider offered), if the transformations and vision of leaders goes beyond the boundaries of the organization.

This scheme corresponds to Mintzberg's view of leadership as mediating force between changing environment and organizational operating system, but at the same time absorbs other more recent findings in leadership literature.

\section{Conclusions and discussion}

The organizational change takes place in daily routine of any organization, and the clear vision of its content and processes is crucial for the strategic battle in markets. But in our opinion, the causes-consequences analyses can become a powerful tool in organizational changes analysis. To ensure success, strategists have to understand the endogenous and exogenous sources of change and their interactions. The research presented the leadership as a mediator between environment and organization system that can be discussed in further research, as we admit that the boundaries of leadership are not clear to impose this particular role. The paper is concentrated on the findings and results of previous studies mostly, but at the same time offers four-element model for the change leadership that must be developed in future. Research on change leadership is needed as far as change leadership can take different forms - from individual to diffused, from competition between managers and leaders to cooperation between change forces - to the network leadership. It is assumed that change is complex, diverse and requires further study of the interactions between displayed change forces. There is only suggestion for dissection the leadership phenomenon into the transformational leaders, change agents, changes operators, its appropriateness must have additional proves, as leader can play all these roles being successful.

\section{Recommendations}

The agenda for future research is about developing an operative tool for practitioners in order to evaluate the real impact of the transformational leadership in organizational change. Both from quantitative and qualitative perspective, an integrative empirical work is needed in a large scope of fields. At the same time, in order to disentangle the leadership phenomenon that encompasses actions of multiple actors like transformational leaders, change agents and change operators, a longitudinal empirical research would be a helpful approach. Finally, there is still a gap in the literature about tangible evidences on the link between the leadership phenomenon, which is a qualitative object, and organizational performance, which is more a quantitative object.

\section{Acknowledgements}

This research was supported by European Union Programme Erasmus Mundus BACKIS (2012-2741 / 001-001 EMA2). I thank my colleagues from University of Montpellier and Sumy State University who provided insights and expertise that greatly assisted the research, although they may not agree with all of the interpretations of this paper. I thank Amel Charleux (UM, MOMA) for her comments that greatly improved the paper. 


\section{References}

1. Adizes, I. (1979). Organizational passages - diagnosing and treating lifecycle problems of organizations. Organizational dynamics, 8(1), 3-25.

2. Aldrich, H.E., \& Pfeffer, J. (1976). Environments of organizations. Annual review of sociology, 79-105.

3. Alvesson, M., \& Kärreman, D. (2016). Intellectual failure and ideological success in organization studies: The case of transformational leadership. Journal of Management Inquiry, 25(2), 139-152.

4. Amburgey, T.L., Kelly, D., \& Barnett, W.P. (1990, August). Resetting the clock: The dynamics of organizational change and failure. In Academy of Management Proceedings, Academy of Management.

5. Armenakis, A.A., \& Bedeian, A.G. (1999). Organizational change: A review of theory and research in the 1990s. Journal of Management, 25(3), 293-315.

6. Avolio, B.J., Bass, B.M., \& Jung, D.I. (1999). Re-examining the components of transformational and transactional leadership using the Multifactor Leadership. Journal of occupational and organizational psychology, 72(4), 441-462.

7. Barnett, W.P., \& Carroll, G.R. (1995). Modeling internal organizational change. Annual review of sociology, 21(1), 217-236.

8. Bass, B.M. (1997). Does the transactional-transformational leadership paradigm transcend organizational and national boundaries? American Psychologist, 52(2), 130.

9. Bass, B.M. (1999). Two decades of research and development in transformational leadership. European journal of work and organizational psychology, 8(1), 9-32.

10. Bass, B.M., \& Riggio, R.E. (2006). Transformational leadership. Psychology Press.

11. Brewer, J. (1987). Exploitation in the new Marxism of collective action. The Sociological Review, 35(1), 84-96.

12. Burawoy, M. (2003). For a sociological Marxism: the complementary convergence of Antonio Gramsci and Karl Polanyi. Politics \& Society, 31(2), 193-261.

13. Burke, W. (1986). Leadership as empowering others. Executive power, 51-77.

14. Burke, W.W., \& Litwin, G.H. (1992). A causal model of organizational performance and change. Journal of Management, 18(3), 523-545.

15. By, R. T., Hughes, M., \& Ford, J. (2016). Change leadership: Oxymoron and myths.

16. Cohen, M.D., March, J.G., \& Olsen, J.P. (1972). A garbage can model of organizational choice. Administrative science quarterly, 1-25.

17. D'Aveni, R. A. (1998). Waking up to the new era of hypercompetition. Washington Quarterly, 21(1), 183-195.

18. Eagly, A. H., Johannesen-Schmidt, M. C., \& Van Engen, M. L. (2003). Transformational, transactional, and laissez-faire leadership styles: a meta-analysis comparing women and men.

19. Eisenbeiss, S. A., van Knippenberg, D., \& Boerner, S. (2008). Transformational leadership and team innovation: integrating team climate principles. Journal of applied psychology, 93(6), 1438.

20. Ensley, M. D., Hmieleski, K. M., \& Pearce, C. L. (2006). The importance of vertical and shared leadership within new venture top management teams: Implications for the performance of startups. The Leadership Quarterly, 17(3), 217-231.

21. García-Morales, V.J., Jiménez-Barrionuevo, M.M., \& Gutiérrez-Gutiérrez, L. (2012). Transformational leadership influence on organizational performance through organizational learning and innovation. Journal of Business Research, 65(7), 1040-1050.

22. Golden, J.H. (2016). Examining Relationships between Transformational Leadership and Employee Creativity and Innovation Performance: The Moderator Effects of Organizational Culture (Doctoral dissertation).

23. Golder, P.N., \& Tellis, G.J. (1993). Pioneer advantage: Marketing logic or marketing legend? Journal of Marketing Research, 158-170.

24. Graetz, F. (2000). Strategic change leadership. Management decision, 38(8), 550-564.

25. Greiner, L.E. (1997, Reprinted from 1972). Evolution and revolution as organizations grow. Harvard business review, No 76(3), 55-60.

26. Gronn, P. (1999). Substituting for leadership: The neglected role of the leadership couple. The Leadership Quarterly, 10(1), 41-62.

27. Gumusluoğlu, L., \& Ilsev, A. (2009). Transformational leadership and organizational innovation: the roles of internal and external support for innovation. Journal of Product Innovation Management, 26(3), 264-277.

28. Halliday, T.C., Powell, M.J., \& Granfors, M.W. (1993). After minimalism: Transformations of state bar associations from market dependence to state reliance, 1918 to 1950. American Sociological Review, 515-535. 
29. Hamel, G., \& Prahalad, C. K. (2013). Competing for the Future. Harvard Business Press.

30. Hamel, G. (2006). The why, what, and how of management innovation. Harvard Business Review, 84(2), 72.

31. Hannan, M. T., \& Freeman, J. (1977). The population ecology of organizations. American Journal of Sociology, 82(5), 929-964.

32. Hannan, M. T., \& Freeman, J. (1984). Structural inertia and organizational change. American sociological review, 149-164.

33. Judge, T.A., \& Piccolo, R.F. (2004). Transformational and transactional leadership: a meta-analytic test of their relative validity. Journal of applied psychology, 89(5), 755.

34. Jung, D.D., Wu, A., \& Chow, C.W. (2008). Towards understanding the direct and indirect effects of CEOs' transformational leadership on firm innovation. The Leadership Quarterly, 19(5), 582-594.

35. Jung, D.I., Chow, C., \& Wu, A. (2003). The role of transformational leadership in enhancing organizational innovation: Hypotheses and some preliminary findings. The Leadership Quarterly, 14(4), 525-544.

36. Kanungo, R.N. (2001). Ethical values of transactional and transformational leaders. Canadian Journal of Administrative Sciences/Revue Canadienne des Sciences de l'Administration, 18(4), 257-265

37. Kirkbride, P. (2006). Developing transformational leaders: the full range leadership model in action. Industrial and commercial training, 38(1), 23-32.

38. Kraatz, M.S., \& Zajac, E.J. (2001). How organizational resources affect strategic change and performance in turbulent environments: Theory and evidence. Organization Science, 12(5), 632-657.

39. Merton, R.K. (1936). The unanticipated consequences of purposive social action. American sociological review, 1(6), 894-904.

40. Meyer, J. W. (2010). World society, institutional theories, and the actor. Annual review of sociology, 36, 1-20.

41. Mintzberg, H. (1978). Patterns in strategy formation. Management science, 24(9), 934-948.

42. Mintzberg, H. (1987). The strategy concept I: Five Ps for strategy. California Management Review, $30(1), 11-24$.

43. Liu, Y. (2013). Sustainable competitive advantage in turbulent business environments. International Journal of Production Research, 51(10), 2821-2841.

44. Oliver, C. (1997). Sustainable competitive advantage: Combining institutional and resource-based views. Strategic Management Journal, 697-713.

45. Pfeffer, J., \& Salancik, G.R. (2003). The external control of organizations: A resource dependence perspective. Stanford University Press.

46. Porras, J.I., \& Robertson, P.J. (1992). Organizational development: Theory, practice, and research. Consulting Psychologists Press.

47. Powell, W.W., \& DiMaggio, P.J. (Eds.). (2012). The new institutionalism in organizational analysis. University of Chicago Press.

48. Reed, R., \& DeFillippi, R.J. (1990). Causal ambiguity, barriers to imitation, and sustainable competitive advantage. Academy of Management Review, 15(1), 88-102.

49. Rubin, R.S., Munz, D.C., \& Bommer, W.H. (2005). Leading from within: The effects of emotion recognition and personality on transformational leadership behavior. Academy of Management Journal, $48(5), 845-858$.

50. Sarros, J.C., Cooper, B.K., \& Santora, J.C. (2008). Building a climate for innovation through transformational leadership and organizational culture. Journal of Leadership \& Organizational Studies, 15(2), 145-158.

51. Schneider, M. (2002). A stakeholder model of organizational leadership. Organization Science, 13(2), 209-220.

52. Shvindina, H. (2016). Identyfikacija sutnosti stratehiji orhanizacijnoho rozvytku (The identification of the essence of the organizational development strategy). Intellect-XXI, 6, 153-160.

53. Sørensen, J.B., \& Stuart, T.E. (2000). Aging, obsolescence, and organizational innovation. Administrative Science Quarterly, 45(1), 81-112.

54. Swedberg, R. (2001). Sociology and game theory: Contemporary and historical perspectives. Theory and Society, 30(3), 301-335.

55. Tushman, M.L., \& Anderson, P. (1990). Technological discontinuities and organizational environments. Administrative science quarterly, 35 (90), 604-633.

56. Tushman, M.L., \& Romanelli, E. (2008). Organizational evolution. Organization change: A comprehensive reader, 155(2008), 174. 
57. Van de Ven, A.H., \& Poole, M.S. (1995). Explaining development and change in organizations. Academy of Management Review, 20(3), 510-540.

58. Wang, G., Oh, I.S., Courtright, S.H., \& Colbert, A.E. (2011). Transformational leadership and performance across criteria and levels: A meta-analytic review of 25 years of research. Group \& Organization Management, 36(2), 223-270.

59. Weick, K.E., \& Quinn, R.E. (1999). Organizational change and development. Annual Review of Psychology, 50(1), 361-386.

60. Yukl, G. (1999). An evaluation of conceptual weaknesses in transformational and charismatic leadership theories. The Leadership Quarterly, 10(2), 285-305. 